\title{
FAKTOR - FAKTOR YANG BERPENGARUH TERHADAP PENERAPAN KESELAMATAN PASIEN DI RUANGAN RAWAT INAP RSU PERMATA MADINA PANYABUNGAN
}

\author{
Ummi Kalsum $^{1}$, Asriwati ${ }^{2}$, Tengku Moriza ${ }^{3}$ \\ ${ }^{1,2,3}$ Institut Kesehatan Helvetia, Medan, Indonesia \\ Email: drgnasution61@gmail.com
}

\begin{abstract}
Abstrak
Keselamatan pasien merupakan suatu sistem yang membuat asuhan pasien menjadi lebih aman. petugas kesehatan sering salah mengidentifikasi pasien, identifikasi dan pengelolaan risiko pasien yang kurang tepat, pelaporan dan analisis insiden yang kurang sesuai, serta kurang memberikan solusi untuk meminimalkan timbulnya risiko dan mencegah terjadinya cedera yang disebabkan oleh kesalahan akibat melaksanakan suatu tindakan atau tidak mengambil tindakan yang seharusnya diambil. Tujuan penelitian ini adalah untuk menganalisa faktor-faktor yang berpengaruh terhadap penerapan keselamatan pasien di ruangan rawat inap RSU Permata Madina Panyabungan. Penelitian ini menggunakan metode survei analitik dengan desain cross sectional. Populasi dalam penelitian ini sebanyak 35 orang. Teknik pengambilan sampel dalam penelitian ini dengan menggunakan metode total sampling. Penelitian ini menggunakan data primer yang diperoleh secara langsung dengan membagikan kuesioner, kemudian dilakukan uji Chi Square dengan nilai kemaknaan $95 \%(=0,05 \%)$. Hasil penelitian menunjukkan ada pengaruh pengetahuan dan supervisi terhadap penerapan keselamatan pasien di ruangan rawat inap Rumah Sakit Permata Madina Panyabungan dengan nilai $\rho$ value $=0,000$, dan $\rho 0,038$. Tidak ada pengaruh sikap dan beban kerja terhadap penerapan keselamatan pasien di ruangan rawat inap Rumah Sakit Permata Madina Panyabungan dengan nilai $\rho$ value $=0,081$ dan $\rho$ value 0,126. Kesimpulan dari penelitian ini adalah ada pengaruh yang signifikan antara pengetahuan dan supervisi terhadap penerapan keselamatan pasien di ruangan rawat inap Rumah Sakit Permata Madina Panyabungan. Tidak ada pengaruh sikapdan beban kerja terhadap penerapan keselamatan pasien di ruangan rawat inap Rumah Sakit Permata Madina Panyabungan. Disarankan kepada pihak manajemen RSU Permata Madina Panyabungan dapat memberikan pelatihan kepada semua Perawat pelaksana tentang penerapan keselamatan pasien.
\end{abstract}

Kata kunci : Pengetahuan, Sikap, Beban Kerja, Supervisi, KeselamatanPasien

\begin{abstract}
Patient safety is a system that makes patient care safer. Health workers often identify patients incorrectly, identify and manage patient risks that are not appropriate, report and analyze incidents that are not appropriate, and do not provide solutions to minimize risks and prevent injuries caused by errors due to carrying out an action or not taking the appropriate action. taken. The purpose of this study was to analyze the factors that influence the implementation of patient safety in the inpatient room of Permata Madina Panyabungan General Hospital. This study used an analytical survey method with a cross sectional design. The population in this study were 35 people. The sampling technique in this study was using the total sampling method. This study uses primary data obtained directly by distributing questionnaires, then the Chi Square test is carried out with a significance value of $95 \%(=0.05 \%)$. The results showed that there was a significant
\end{abstract}


effect between knowledge and supervision on the implementation of patient safety in the inpatient room at Permata Madina Panyabungan Hospital dengan nilai $\rho$ value $=0,000$, and $\rho 0,038$. There is no influence of attitude and workload on the implementation of patient safety in the inpatient room at Permata Madina Panyabungan Hospital nilai $\rho$ value $=0,081$ and $\rho$ value 0,126. The conclusion of this study is that there is a significant influence between knowledge and supervision on the implementation of patient safety in the inpatient room at Permata Madina Hospital Panyabungan. There is no influence of attitude and workload on the implementation of patient safety in the inpatient room at Permata Madina Panyabungan Hospital. It is suggested to the management of Permata Madina Panyabungan General Hospital to provide training to all implementing nurses on the application of patient safety.

Keywords : Knowledge, Attitude, Workload, Supervision, Safety Patient

\section{Pendahuluan}

Rumah sakit adalah institusi pelayanan kesehatan bagi masyarakat dengan karakteristik tersendiri yang di pengaruhi oleh perkembangan ilmu pengetahuan kesehatan, kemajuan teknologi, dan kehidupan sosial ekonomi masyarakat yang mampu meningkatkan pelayanan yang lebih bermutu dan terjangkau oleh masyarakat agar terwujud derajat kesehatan yang setinggitingginya (Undang-undang Kesehatan nomor 44 tahun 2009). Rumah sakit wajib melaksanakan pelayanan kesehatan yang paripurna yakni aman, bermutu, anti diskriminasi dan efektif, dengan mengutamakan kepentingan pasien. Pelayanan yang disediakan rumah sakit berupa rawat jalan, rawat inap dan gawat darurat, hal ini tertuang dalam Permenkes No.340/MENKES/PER/III/2010.

Keselamatan (safety) telah menjadi isu global dalam dunia kesehatan. Ada lima isu penting yang terkait dengan keselamatan (safety) di rumah sakityaitu : keselamatan pasien (patient safety), keselamatan pekerja atau petugas, keselamatan bangunan dan peralatan di rumah sakit yang bisa berdampak terhadap pasien dan petugas, keselamatan lingkungan (green productivity), yang berdampak terhadap pencemaran lingkungan dan keselamatan rumah sakit yang terkait dengan kelangsungan rumah sakit. Kelima aspek keselamatan tersebutsangatlah penting untuk dilaksanakan di setiap rumah sakit. Namun harus diakui kegiatan institusi rumah sakit dapat berjalan apabila ada pasien. Karena itu keselamatan pasien merupakan prioritas utama untuk di laksanakan dan hal tersebut terkait dengan isu mutu dan citra perumahsakitan. (Permenkes RI Nomor 1691)

Keselamatan pasien merupakan suatu sistem yang membuat asuhan pasien menjadi lebih aman. Keselamatan pasien merupakan masalah kesehatan yang sangat penting saat ini, dimana masih banyak terjadi kesalahan medis terhadap pasien. Kesalahan medis yang sering terjadi merupakan suatu kegagalan pelayanan kesehatan yang tidak sesuai dengan rencana atau perencanaan yang sudah tepat namun pada pelaksanaannya yang tidak tepat. Dampak dari kesalahan tersebut berisiko dapat berpotensi menimbulkan Insiden Keselamatan Pasien (IKP). Oleh karena itu perhatian terhadap keselamatan pasien menjadi penting dalam pemberian pelayanan kesehatan. Hal ini tercantum dalam Undang-undang Kesehatan Republik Indonesia Nomor 36 Tahun 2009 pasal 53 ayat (3) yang menyatakan bahwa pelaksanan pelayanan kesehatan harus 
mendahulukan keselamatan nyawa pasien dibanding lainnya.

Pelayanan kesehatan pada dasarnya untuk menyelamatkan pasien sesuai dengan yang di ucapkan Hipocrates kira-kira 2400 tahun yang lalu yaitu Primum, non nocere (first, do no harm). Namun dengan semakin berkembangnya ilmu dan teknologi pelayanan kesehatan khususnya di rumah sakit menjadi semakin kompleks dan bepotensi kejadian tidak diharapkan (Adverse event) apabila tidak dilakukan dengan hati-hati.

Menurut Vincent, ada beberapa faktor yang berpengaruh terhadap keselamatan pasien, yaitu: pengetahuan, sikap, beban kerja, dan supervisi. Wawan dan Dewi mendeskripsikan bahwa pengetahuan merupakan hasil "tahu" dan ini terjadi setelah orang mengadakan penginderaan terhadap suatu objek tertentu.(Wawan, dkk, 2010) Pengetahuan tentang berbagai cara dalam mencapai pemeliharaan kesehatan, cara menghindari penyakit, maka akan meningkatkan pengetahuan masyarakat. (Priyanto, 2018) Pengetahuan tentang penerapan keselamatan pasien merupakan hal yang sangat penting agar tidak menimbulkan peningkatan jumlah kasus keselamatan pasien. (Mona, 2020)

Pengetahuan dari perawat dapat diartikan sebagai hasil tahu dari perawat mengenai penerapan keselamatan pasien, memahami penerapan keselamatan pasien. Pengetahuan memegang peranan penting dalam penentuan perilaku yang utuh karena pengetahuan akan membentuk kepercayaan yang selanjutnya dalam mempersepsikan kenyataan, memberikan dasar bagi pengambilan keputusan dan menentukan perilaku terhadap objek tertentu sehingga akan mempengaruhi seseorang dalam berperilaku. (Priyanto, 2018)

Sikap adalah keadaan mental dari kesiapan, yang diatur melalui pengalaman yang memberikan pengaruh dinamik atau terarah terhadap respon individu pada semua obyek dan situasi yang berkaitan dengannya. Terbentuk suatu perilaku baru terutama pada orang dewasa dimulai pada domain kognitif dalam arti subyek tahu terlebih dahulu terhadap stimulus yang berupa materi atau obyek di luarnya, sehingga menimbulkan pengetahuan baru dan akan terbentuk dalam sikap maupun tindakan. (Widayatun, 2009)

Profesionalitas tenaga kesehatan khususnya perawat yang ditunjuk sebagai pemberi layanan kesehatan dalam melaksanakan program menjaga keselamatan pasien (patient safety) berdasarkan standar pelayanan kesehatan, mandiri, bertanggung jawab dan bertanggung gugat, serta mengembangkan kemampuan sesuai dengan perkembangan ilmu pengetahuan dan teknologi. Profesionalitas tersebut harus terus dipelihara dan ditingkatkan dalam rangka mempertahankan standar pelayanan yang tinggi. Perawat sebagai salah satu komponen utama pemberi layanan kesehatan, memiliki peran penting karena terkait langsung maupun tidak langsung sesuai dengan kemampuan yang dimilikinya. Perawat sebagai ujung tombak pelayanan kesehatan yang ada di lapangan sangat menentukan dalam upaya pencegahan dan pemutusan rantai transmisi infeksi dalam rangka memenuhi kebutuhan keamanan pasien. (Hasana, dkk, 2017)

Tugas dan tanggung jawab perawat bukan hal yang ringan untuk dipikul, di satu sisi perawat bertanggung jawab terhadap tugas fisik, administratif, dari instansi tempat ia bekerja, disamping itu perawat juga menghadapi kecemasan, keluhan dan mekanisme 
pertahanan diri pasien yang muncul pada pasien akibat sakitnya. Ketegangan, kejenuhan dalam menghadapi pasien dalam kondisi yang menderita sakit kritis atau keadaan terminal, disisi lain perawat dituntut untuk selalu tampil sebagai profil perawat yang baik oleh pasiennya. Berbagai situasi dan tuntutan kerja yang dialami perawat dapat menjadi penyebab kurang memperhatikan penerapan keselamatan pasien.(Suryani, 2013)

Perilaku penerapan keselamatan pasien oleh perawat dapat ditingkatkan melalui kegiatan supervisi pelayanan keperawatan. Supervisi merupakan pengamatan secara langsung dan berkala oleh "atasan" terhadap pekerjaan yang dilakukan "bawahan" untuk kemudian bila ditemukan masalah, segera diberikan bantuan yang bersifat langsung guna mengatasinya. (Gibson, 2003)

Hasil survei awal yang dilakukan peneliti dari bulan Juni 2021 sampai bulan Juli 2021 di ruangan rawat inap Rumah Sakit Umum Permata Madina Panyabungan, peneliti menemukan bahwa masih ada petugas kesehatan yang kurang memperhatikan keselamatan pasien. Hasil pengamatan yang dilakukan peneliti menemukan bahwa masih ada petugas kesehatan yang salah mengidentifikasi pasien, identifikasi dan pengelolaan risiko pasien yang kurang tepat, pelaporan dan analisis insiden yang kurang sesuai, serta kurang memberikan solusi untuk meminimalkan timbulnya risiko dan mencegah terjadinya cederayang disebabkan oleh kesalahan akibat melaksanakan suatu tindakan atau tidak mengambil tindakan yang seharusnya diambil.

Hasil wawancara yang dilakukan peneliti terhadap lima orang perawat, tiga orang perawat mengatakan bahwa supervisi yang dilakukan oleh kepala ruang bersamaan dengan kegiatan operan dan hanya dalam bentuk pengawasan serta tidak memberikan pengarahan, bimbingan, maupun evaluasi. Perawat mengatakan jika tidak menerapkan sasaran keselamatan pasien, kepala ruang tidak pernah menegur secara langsung namun hanya diingatkan saat pre conference, dan dua orang perawat mengatakan bahwa supervisi yang dilakukan selama ini oleh kepala ruang di Rumah Sakit Umum Permata Madina Panyabungan tidak terjadwal, bahan yang disupervisi tidak jelas, hasil supervisi tidak disampaikan kepada perawat yang disupervisi, dan supervisi yang dilakukan hanya sebatas mengamati serta mencatat.

Rumah sakit umum Perrmata Madina merupakan satu-satunya rumah sakit Umum swasta yang berada di Panyabungan Kabupaten Mandailing Natal yang sudah terakreditasi, sehingga peneliti tertarik untuk meneliti faktor-faktor yang berpengaruh terhadap penerapan keselamatann pasien di Rumah Sakit tersebut.

\section{Metode Penelitian}

Penelitian ini merupakan penelitian survei analitik, dimana peneliti ingin menggali apa saja faktor-faktor yang berpengaruh terhadap penerapan keselamatan pasien di ruangan rawat inap Rumah Sakit Umum Permata Madina Panyabungan dan mengapa fenomena kesehatan itu terjadi dengan menggunakan pendekatan cross sectional dimana variabel dependen dan variabel independen diteliti secara bersamaan. Populasi dalam penelitian ini adalah perawat pelaksana yang merupakan pegawai tetap dan bertugas diruangan rawat inap Rumah Sakit Umum Permata Madina Panyabungan 
sebanyak 35 orang. Jumlah sampel yang digunakan dalam penelitian ini berjumlah 35 reponden. Analisis data yang dilakukan adalah analisis univariat, bivariat dan multivariat. Berikut adalah penjelasannya.

\section{Hasil Penelitian}

Tabel 1. Distribusi Frekuensi Jenis Kelamin Perawat di RuanganRawat Inap Rumah Sakit Umum Permata Madina Panyabungan

\begin{tabular}{lcrr}
\hline Jenis Kelamin & $\mathrm{f}$ & $\%$ \\
\hline Laki-laki & 12 & 34,3 \\
Perempuan & 23 & 65,7 \\
\hline & Total & 35 & 100,0 \\
\hline & & $\mathrm{f}$ & \\
\hline Pendidikan & 21 & 60,0 \\
\hline D III & 3 & 8,6 \\
D IV & 11 & 31,4 \\
\hline S1 & Total & 35 & 100,0 \\
\hline
\end{tabular}

Tabel 1. di atas, menunjukkan bahwa jumlah responden yang berpendidikan DIII Keperawatan sebanyak 21 responden $(60,0 \%)$, jumlah responden yang berpendidikan D IV Keperawatan sebanyak 3 responden $(8,6 \%)$, dan jumlah responden yang berpendidikan S1 Keperawatan sebanyak 11 responden $(31,4 \%)$.

\section{Analisa Univariat}

Hasil analisa univariat tentang faktor-faktor yang berhubungan denganpenerapan keselamatan pasien di ruangan rawat inap Rumah Sakit Umum Permata Madina Panyabungan dapat dilihat pada tabel berikut ini

Tabel 2. Distribusi Frekuensi Jawaban Pengetahuan Perawat dalam Penerapan Keselamatan Pasien di Ruangan Rawat Inap RSUPermata Madina Panyabungan

\begin{tabular}{|l|l|c|c|c|c|c|c|}
\hline \multirow{2}{*}{ No } & \multicolumn{1}{|c|}{ Pernyataan } & \multicolumn{2}{c|}{ Ya } & \multicolumn{2}{c|}{ Tidak } & \multicolumn{3}{c|}{ Total } \\
\cline { 3 - 7 } & & $\mathrm{f}$ & $\%$ & $\mathrm{f}$ & $\%$ & $\mathrm{f}$ & $\%$ \\
\hline 1 & $\begin{array}{l}\text { Keselamatan pasien merupakan suatu system } \\
\text { yang membuat asuhan pasien yang lebih aman }\end{array}$ & 24 & 68,6 & 11 & 31,4 & 35 & 100,0 \\
\hline 2 & $\begin{array}{l}\text { Mengidentifikasi pasien dengan benar merupakan } \\
\text { salah satu sasaran keselamatan pasien. }\end{array}$ & 18 & 51,4 & 17 & 48,6 & 35 & 100,0 \\
\hline 3 & $\begin{array}{l}\text { Hak pasien, pendidikan bagipasien dan keluarga } \\
\text { termasuk dalam standar keselamatan pasien. }\end{array}$ & 24 & 68,6 & 11 & 31,4 & 35 & 100,0 \\
\hline 4 & $\begin{array}{l}\text { Kondisi dimana sudah terjadinya insiden tetapi } \\
\text { belum terpapar pada pasiendisebut Kejadian } \\
\text { Nyaris Cedera (KNC) }\end{array}$ & 17 & 48,6 & 18 & 51,4 & 35 & 100,0 \\
\hline
\end{tabular}

Tabel 2. di atas, menunjukkan bahwa lebih banyak responden yang menjawab pernyataan pada item pertama dan item ketiga. Pernyataan pada item pertama yaitu: 
keselamatan pasien merupakan suatu sistem yang membuat asuhan pasien lebih aman, dan pernyataan pada item ketiga yaitu: hak pasien, pendidikan bagi pasien dan keluarga termasuk dalam standar keselamatan pasien. Keduapernyataan tersebut dijawab ya oleh 24 responden $(68,6 \%)$ dan dijawab tidak oleh 11 responden $(31,4 \%)$. Pernyataan yang paling banyak dijawab tidak oleh responden yaitu pernyataan pada item keempat, dengan pernyataan: kondisi dimana sudah terjadinya insiden tetapi belum terpapar pada pasien disebut Kejadian Nyaris Cedera (KNC). Pernyataan tersebut merupakan pernyataan yang paling banyak dijawab tidak oleh responden sebanyak 18 responden $(51,4 \%)$, dan jumlah responden yang menjawab ya sebanyak 17 responden $(48,6 \%)$.

Tabel 4.4. Distribusi Frekuensi Pengetahuan Perawat dalam Penerapan Keselamatan Pasien di Ruangan Rawat Inap RSU Permata Madina PanyabunganTabel 4.3 di atas, menunjukkan bahwa lebih banyak responden yang menjawab pernyataan pada item pertama dan item ketiga. Pernyataan pada item pertama yaitu: keselamatan pasien merupakan suatu sistem yang membuat asuhan pasien lebih aman, dan pernyataan pada item ketiga yaitu: hak pasien, pendidikan bagi pasien dan keluarga termasuk dalam standar keselamatan pasien. Kedua pernyataan tersebut dijawab ya oleh 24 responden $(68,6 \%)$ dan dijawab tidak oleh 11 responden $(31,4 \%)$. Pernyataan yang paling banyak dijawab tidak oleh responden yaitu pernyataan pada item keempat, dengan pernyataan: kondisi dimana sudah terjadinya insiden tetapi belum terpapar pada pasien disebut Kejadian Nyaris Cedera (KNC). Pernyataan tersebut merupakan pernyataan yang paling banyak dijawab tidak oleh responden sebanyak 18 responden $(51,4 \%)$, dan jumlah responden yang menjawab ya sebanyak 17 responden $(48,6 \%)$.

Distribusi Frekuensi Pengetahuan Perawat dalam Penerapan Keselamatan Pasien di Ruangan Rawat Inap RSU Permata Madina Panyabungan Tabel 4.3 di atas, menunjukkan bahwa lebih banyak responden yang menjawab pernyataan pada item pertama dan item ketiga. Pernyataan pada item pertama yaitu: keselamatan pasien merupakan suatu sistem yang membuat asuhan pasien lebih aman, dan pernyataan pada item ketiga yaitu: hak pasien, pendidikan bagi pasien dan keluarga termasuk dalam standar keselamatan pasien. Kedua pernyataan tersebut dijawab ya oleh 24 responden $(68,6 \%)$ dan dijawab tidak oleh 11 responden $(31,4 \%)$. Pernyataan yang paling banyak dijawab tidak oleh responden yaitu pernyataan pada item keempat, dengan pernyataan: kondisi dimana sudah terjadinya insiden tetapi belum terpapar pada pasien disebut Kejadian Nyaris Cedera (KNC). Pernyataan tersebut merupakan pernyataan yang paling banyak dijawab tidak oleh responden sebanyak 18 responden $(51,4 \%)$, dan jumlah responden yang menjawab ya sebanyak 17 responden $(48,6 \%)$.

Tabel 3. Distribusi Frekuensi Jawaban Sikap Perawat dalam PenerapanKeselamatan Pasien di Ruangan Rawat Inap RSU Permata Madina Panyabungan

\begin{tabular}{|l|l|c|c|c|c|c|c|}
\hline \multirow{2}{*}{ No } & \multicolumn{1}{|c|}{ Pernyataan } & \multicolumn{2}{|c|}{ Ya } & \multicolumn{2}{c|}{ Tidak } & \multicolumn{2}{c|}{ Total } \\
\cline { 3 - 7 } & $\mathrm{f}$ & $\%$ & $\mathrm{f}$ & $\%$ & $\mathrm{f}$ & $\%$ \\
\hline 1 & $\begin{array}{l}\text { Dengan menerapkan sistem } \\
\text { keselamatan pasien di rumah } \\
\text { sakit akan membuat pasien } \\
\text { menjadi lebih aman }\end{array}$ & 31 & 88,6 & 4 & 11,4 & 35 & 100,0 \\
\hline 2 & $\begin{array}{l}\text { Menurut saya melakukan } \\
\text { identifikasi pasien dengan benar } \\
\text { sangat perlu dilakukanoleh } \\
\text { perawat pelaksana }\end{array}$ & 25 & 71,4 & 10 & 28,6 & 35 & 100,0 \\
\hline 3 & $\begin{array}{l}\text { Setiap terjadinya insiden } \\
\text { keselamatan pasien harus } \\
\text { dilaporkan, bukan untuk ditutupi }\end{array}$ & 32 & 91,4 & 3 & 8,6 & 35 & 100,0 \\
\hline
\end{tabular}




\begin{tabular}{|l|l|l|l|l|l|l|l|}
\hline & atau disembunyikan & & & & & & \\
\hline 4 & $\begin{array}{l}\text { Menurut saya sangat penting } \\
\text { diperhatikannyakeamanan } \\
\text { terhadap obat-obatan yang harus } \\
\text { si waspadai }\end{array}$ & 27 & 77,1 & 8 & 22,9 & 35 & 100,0 \\
\hline
\end{tabular}

Tabel 3. di atas, menunjukkan bahwa lebih banyak responden yang menjawab pernyataan pada item ketiga dengan pernyataan: setiap terjadinya insiden keselamatan pasien harus dilaporkan, bukan untuk ditutupi atau disembunyikan. Pernyataan tersebut dijawab ya oleh 32 responden $(91,4 \%)$ dan dijawab tidak oleh 3 responden $(8,6 \%)$. Pernyataan yang paling banyak dijawab tidak oleh responden yaitu pernyataan pada item dua dengan pernyataan yaitu: menurut saya melakukan identifikasi pasien dengan benar sangat perlu dilakukan oleh perawat pelaksana. Pernyataan tersebut paling banyak dijawab tidak oleh responden sebanyak 10 responden $(28,6 \%)$, dan jumlah responden yangmenjawab ya sebanyak 25 responden $(71,4 \%)$.

Tabel 4. Distribusi Frekuensi Sikap Perawat dalam Penerapan Keselamatan Pasien di Ruangan Rawat Inap RSU PermataMadina Panyabungan

\begin{tabular}{ccc}
\hline Sikap & $\mathrm{f}$ & $\%$ \\
\hline Baik & 30 & 85,7 \\
Kurang baik & 5 & 14,3 \\
\hline Total & 35 & 100,0 \\
\hline
\end{tabular}

Tabel 4. di atas, menunjukkan bahwa lebih banyak jumlah responden yang bersikap dengan kategori baik dalam penerapan keselamatan pasien di ruangan rawat inap Rumah Sakit Umum Permata Madina Panyabungan sebanyak 30 responden (94,3\%), dan lebih sedikit responden yang bersikap dengan kategori kurang baik dalam penerapan keselamatan pasien responden yang bersikap dengan kategori kurang baik dalam penerapan keselamatan pasien sebanyak 5 responden $(14,3 \%)$.

Tabel 5. Distribusi Frekuensi Jawaban Beban Kerja Perawat dalam Penerapan Keselamatan Pasien di Ruangan Rawat Inap RSUPermata Madina Panyabungan

\begin{tabular}{|c|c|c|c|c|c|c|c|}
\hline \multirow{2}{*}{ No } & Pernyatan & \multicolumn{2}{|c|}{ Ya } & \multicolumn{2}{|c|}{ Tidak } & \multicolumn{2}{|c|}{ Total } \\
\cline { 3 - 8 } & $\mathrm{f}$ & $\%$ & $\mathrm{f}$ & $\%$ & $\mathrm{f}$ & $\%$ \\
\hline 2 & $\begin{array}{c}\text { Banyaknya pekerjaan yang harus } \\
\text { dilakukan demi keselamatan } \\
\text { pasien }\end{array}$ & 24 & 68,6 & 11 & 31,4 & 35 & 100,0 \\
\hline 3 & $\begin{array}{c}\text { Beragamnya jenis pekerjaan yang } \\
\text { harusdilakukan demi keselamatan } \\
\text { pasien }\end{array}$ & 21 & 60,0 & 14 & 40,0 & 35 & 100,0 \\
\hline 4 & $\begin{array}{c}\text { Kontak langsung perawatdengan } \\
\text { pasien di ruang rawat inap bedah } \\
\text { secara terus-menerus selama jam } \\
\text { kerja }\end{array}$ & 23 & 65,7 & 12 & 34,3 & 35 & 100,0 \\
\hline 4 & $\begin{array}{c}\text { Menyampaikan informasi } \\
\text { mengenai status kesehatan } \\
\text { pasien kepada pasien dan } \\
\text { keluarganya }\end{array}$ & 18 & 51,4 & 17 & 48,6 & 35 & 100,0 \\
\hline
\end{tabular}

Tabel 5. di atas, menunjukkan bahwa lebih banyak responden yang menjawab 
pernyataan pada item pertama dengan pernyataan: banyaknya pekerjaan yang harus dilakukan demi keselamatan pasien. Pernyataan tersebut dijawab ya oleh 24 responden $(68,6 \%)$ dan dijawab tidak oleh 11 responden $(31,4 \%)$. Pernyataan yang paling banyak dijawab tidak oleh responden yaitu pernyataan pada item keempat dengan pernyataan: menyampaikan informasi mengenai status kesehatan pasien kepada pasien dan keluarganya. pernyataan tersebut paling banyak dijawab tidak oleh responden sebanyak 17 responden $(48,6 \%)$, dan jumlah responden yang menjawab ya sebanyak 18 responden $(51,4 \%)$.

Tabel 6. Distribusi Frekuensi Beban kerja Perawat dalam PenerapanKeselamatan Pasien di Ruangan Rawat Inap RSU Permata Madina Panyabungan

\begin{tabular}{|c|c|c|}
\hline Beban kerja & $\mathrm{f}$ & $\%$ \\
\hline Berat & 17 & 48,6 \\
\hline Ringan & 18 & 51,4 \\
\hline Total & 35 & 100,0 \\
\hline
\end{tabular}

Tabel 6. di atas, menunjukkan bahwa lebih banyak jumlah responden dengan beban kerja kategori ringan dalam penerapan keselamatan pasien di ruangan rawat inap Rumah Sakit Umum Permata Madina Panyabungan sebanyak 18 responden (51,4\%), dan lebih sedikit responden dengan beban kerja kategori berat dalam penerapan keselamatan pasien sebanyak 17 responden $(48,6 \%)$.

Tabel 7. Distribusi Frekuensi Jawaban Supervisi Perawat dalam Penerapan Keselamatan Pasien di Ruangan Rawat Inap RSUPermata Madina Panyabungan

\begin{tabular}{|c|c|c|c|c|c|c|c|}
\hline \multirow{2}{*}{ No } & \multirow{2}{*}{ Pernyataan } & \multirow{2}{*}{$\begin{array}{c}\mathrm{Ya} \\
\mathrm{f} \\
\end{array}$} & \multirow{2}{*}{$\begin{array}{c}\text { Tidak } \\
\%\end{array}$} & \multirow{2}{*}{$\begin{array}{c}\text { Total } \\
\mathrm{f}\end{array}$} & \multirow[b]{2}{*}{$\%$} & \multirow[b]{2}{*}{$\mathrm{f}$} & \multirow[b]{2}{*}{$\%$} \\
\hline & & & & & & & \\
\hline 1 & $\begin{array}{l}\text { Kepala ruangan membimbing saya dan } \\
\text { tenaga kesehatan lainnya dalam } \\
\text { pembentukan tim setiap shift kerja }\end{array}$ & 24 & 68,6 & 11 & 31,4 & 35 & 100,0 \\
\hline 2 & $\begin{array}{l}\text { Kepala ruangan membimbing saya dalam } \\
\text { merencanakankegiatan }\end{array}$ & 14 & 40,0 & 21 & 60,0 & 35 & 100,0 \\
\hline 3 & $\begin{array}{c}\text { Kepala ruangan mengarahkan saya untuk } \\
\text { melaksanakan program patient safety } \\
\text { sesuai standar operasional rumah sakit } \\
\text { yang berlaku }\end{array}$ & 27 & 77,1 & 8 & 22,9 & 35 & 100,0 \\
\hline 4 & $\begin{array}{l}\text { Kepala ruangan bertanggung jawab } \\
\text { untuk mengikuti serah terima_pasien } \\
\text { setiap harinya }\end{array}$ & 18 & 51,4 & 17 & 48,6 & 35 & 100,0 \\
\hline
\end{tabular}

Tabel 7. di atas, menunjukkan bahwa lebih banyak responden yang menjawab pernyataan pada item ketiga dengan pernyataan: kepala ruangan mengarahkan saya untuk melaksanakan program patient safety sesuai standaroperasional rumah sakit yang berlaku. Pernyataan tersebut dijawab ya oleh 27 responden $(77,1 \%)$ dan dijawab tidak oleh 8 responden $(22,9 \%)$. Pernyataan yang paling banyak dijawab tidak oleh responden yaitu pernyataan pada item kedua dengan pernyataan: kepala ruangan membimbing saya dalam merencanakan kegiatan. pernyataan tersebut paling banyak dijawab tidak oleh responden sebanyak 21 responden $(60,0 \%)$, dan jumlah responden yang menjawab ya sebanyak 14 responden $(40,0 \%)$. 
Tabel 8. Distribusi Frekuensi Supervisi Perawat dalam Penerapan Keselamatan Pasien di Ruangan Rawat Inap RSU PermataMadina Panyabungan

\begin{tabular}{|c|c|c|}
\hline Supervisi & $\mathrm{f}$ & $\%$ \\
\hline Baik & 15 & 42,9 \\
\hline Kurang baik & 20 & 57,1 \\
\hline Total & 35 & 100,0 \\
\hline
\end{tabular}

Tabel 8. di atas, menunjukkan bahwa lebih banyak jumlah responden supervisi dengan kategori kurang baik dalam penerapan keselamatan pasien di ruangan rawat inap Rumah Sakit Umum Permata Madina Panyabungan sebanyak 15 responden (42,9\%), dan lebih sedikit responden supervisi dengan kategori baik dalam penerapan keselamatan pasien sebanyak 15 responden $(42,9 \%)$

Tabel 9. Distribusi Frekuensi Jawaban Penerapan Keselamatan Pasiendi Ruangan Rawat Inap RSU Permata Madina Panyabungan

\begin{tabular}{|c|c|c|c|c|c|c|c|}
\hline \multirow{2}{*}{ No } & Pernyataan & \multicolumn{2}{|c|}{ Ya } & \multicolumn{2}{|c|}{ Tidak } & \multicolumn{2}{c|}{ Total } \\
\cline { 3 - 8 } & f & $\%$ & f & $\%$ & f & $\%$ \\
\hline 1 & $\begin{array}{c}\text { Petugas melaksanakan ketepatan } \\
\text { identifikasi pasien }\end{array}$ & 21 & 60,0 & 14 & 40,0 & 35 & 100,0 \\
\hline 3 & $\begin{array}{c}\text { Petugas kesehatan melaksanakan } \\
\text { peningkatan komunikasi yang efektif }\end{array}$ & 17 & 48,6 & 18 & 51,4 & 35 & 100,0 \\
\hline 4 & $\begin{array}{c}\text { Petugas kesehatan melaksanakan } \\
\text { pengurangan risiko infeksi dengan } \\
\text { menerapkan program hand hygienesesudah } \\
\text { melakukan tindakan pada pasien }\end{array}$ & 21 & 60,0 & 14 & 40,0 & 35 & 100,0 \\
\hline 5 & $\begin{array}{c}\text { Petugas kesehatan menerapkan proses } \\
\text { asesmen awal risikopasienjatuh dan } \\
\text { melakukan asesmen ulang terhadap pasien } \\
\text { bila diindikasikan terjadi perubahan kondisi } \\
\text { atau pengobatan }\end{array}$ & 19 & 54,3 & 16 & 45,7 & 35 & 100,0 \\
\hline $\begin{array}{c}\text { Petugas kesehatan melaksanakan kepastian } \\
\text { tepat lokasi,tepat prosedur tepat pasien } \\
\text { operasi }\end{array}$ & 19 & 54,3 & 16 & 45,7 & 35 & 100,0 \\
\hline
\end{tabular}

Tabel 9. di atas, menunjukkan bahwa lebih banyak responden yangmelaksanakan pernyataan pada item pertama dan pernyataan pada item ketiga. Pernyataan pada item pertama yaitu: petugas melaksanakan ketepatan identifikasi pasien, dan pernyataan pada item ketiga yaitu: petugas kesehatan melaksanakan pengurangan risiko infeksi terkait pelayanan kesehatan dengan menerapkan program hand hygiene yang efektif sebelum dan sesudah melakukan tindakan pada pasien. Masing-masing pernyataan tersebut dilaksanakan oleh 21 responden $(60,0 \%)$, dan tidak dilaksanakan oleh 14 responden (40,0\%). Pernyataan yang paling banyak tidak dilaksanakan oleh responden yaitu permnyataan pada item kedua dengan pernyataan: petugas kesehatan melaksanakan peningkatan komunikasi yang efektif. Pernyataan tersebut paling banyak tidak dilaksanakan oleh 18 responden $(51,4 \%)$, dan dilaksanakan oleh 17 responden $(48,6 \%)$.

Tabel 10. Distribusi Frekuensi Penerapan Keselamatan Pasien di RuanganRawat Inap RSU Permata Madina Panyabungan

\begin{tabular}{|c|c|c|}
\hline Penerapan keselamatan pasien & f & $\%$ \\
\hline Baik & 13 & 37,1 \\
\hline
\end{tabular}




\begin{tabular}{|c|c|c|}
\hline Kurang baik & 22 & 62,9 \\
\hline Total & 35 & 100,0 \\
\hline
\end{tabular}

Tabel 4.12 di atas, menunjukkan bahwa lebih banyak jumlah responden yang menerapkan standar keselamatan pasien di ruangan rawat inap Rumah Sakit Umum Permata Madina Panyabungan dengan kategori kurang baik sebanyak 22 responden $(62,9 \%)$, dan lebih sedikit responden yang menerapkan standar keselamatan pasien dengan kategori baik sebanyak 13 responden $(37,1 \%)$.

\section{Analisa Bivariat}

Hasil analisa bivariat tentang faktor-faktor yang berhubungan dengan penerapan keselamatan pasien di ruangan rawat inap Rumah Sakit Umum Permata Madina Panyabungan dapat dilihat pada tabel sebagai berikut:

Tabel 11. Hubungan Pengetahuan dengan Penerapan Keselamatan Pasiendi Ruangan Rawat Inap Rumah Sakit Umum Permata Madina Panyabungan

\begin{tabular}{|c|c|c|c|c|c|c|c|}
\hline \multirow{3}{*}{ Pengetahuan } & \multicolumn{4}{|c|}{ Penerapan keselamatan pasien } & \multirow{2}{*}{\multicolumn{2}{|c|}{ Jumlah }} & \multirow{3}{*}{$p_{(\mathrm{Sig})}$} \\
\hline & \multicolumn{2}{|c|}{ Baik } & \multicolumn{2}{|c|}{ Kurang Baik } & & & \\
\hline & $\mathrm{f}$ & $\%$ & $\mathrm{f}$ & $\%$ & $\mathrm{f}$ & $\%$ & \\
\hline Baik & 13 & 37,1 & 3 & 8,6 & 16 & 45,7 & \multirow{3}{*}{0.000} \\
\hline Kurang Baik & 0 & 0 & 19 & 62,9 & 19 & 54,3 & \\
\hline Total & 13 & 37,1 & 22 & 55,1 & 35 & 100 & \\
\hline
\end{tabular}

Tabel 11. di atas menunjukkan bahwa dari 16 responden pengetahuan dengan kategori baik, lebih banyak responden yang menerapkan keselamatan pasien di ruangan rawat inap Rumah Sakit Umum Permata Madina Panyabungan dengan kategori baik sebanyak 13 responden $(37,1 \%)$, dan lebih sedikit responden yang menerapkan keselamatan pasien di ruangan rawat inap Rumah Sakit Umum Permata Madina Panyabungan dengan kategori kurang baik sebanyak 3 responden (8,6\%). Dari 19 responden pengetahuan dengan kategori kurang baik, seluruhnya responden menerapkan keselamatan pasien di ruangan rawat inap dengan kategori kurang baik sebanyak 19 responden $(62,9)$.

\section{Hubungan Pengetahuan dengan Penerapan Keselamatan Pasien di Ruangan Rawat Inap Rumah Sakit Umum Permata Madina Panyabungan}

Hasil uji validitas dan reliabilitas kuesioner pengetahuan di ruangan rawat inap Rumah Sakit Umum Daerah Panyabungan menunjukkan bahwa tidak ada data yang mising (tidak dikenal) sehingga data penelitian ini merupakan data yang akurat dan selanjutnya dapat digunakan untuk penelitian. Nilai corrected item total correlaction dari 0,382-0,661 >0,361 menunjukkan bahwa seluruh kuesioner pengetahuan valid. Penyebaran kuesioner khusus dalam uji validitas dan reliabilitas diberikan kepada 30 responden yang memiliki karakteristik yang sama dengan sampel penelitian.

Hasil yang diperoleh menunjukkan bahwa seluruh pernyataan valid, karena seluruh 
pernyataan bernilai lebih besar atau sama dengan nilai $r$ tabel 0,361 . Hasil uji reliabilitas kuesioner pengetahuan di ruangan rawat inap Rumah Sakit Umum Daerah Panyabungan diperoleh nilai $\mathrm{r}$ alpha $>$ tabel $(0,635>0,361)$, hasil ini menunjukan bahwa seluruh kuesioner pengetahuan reliabel.

Hasil penelitian yang dilakukan peneliti terhadap 35 responden di di ruangan rawat inap Rumah Sakit Umum Permata Madina Panyabungan diperoleh bahwa jumlah responden yang berpengetahuan dengan kategori baik sebanyak 16 responden $(45,7 \%)$, dan jumlah responden yang berpengetahuan kurang baik dalam penerapan keselamatan pasien di ruangan rawat inap Rumah Sakit Umum Permata Madina Panyabungan sebanyak 19 responden $(54,3 \%)$.

Hasil uji Chi-square atau Continuity Correction dapat diketahui dengan derajat kemaknaan $(a)=0,05$ maka diperoleh nilai probabilitasnya $(\rho)=0,000<0,05$ menunjukkan bahwa ada hubungan yang signifikan antara pengetahuan dengan penerapan keselamatan pasien di ruangan rawat inap Rumah Sakit Umum Permata Madina Panyabungan.

Hasil penelitian ini sejalan dengan hasil penelitian yang dilakukan oleh Aprilia Roswati dengan nilai $p$ value $=0,002<0,05$ dengan derajat kemaknaan $(\alpha) 0,05$, maka dapat disimpulkan bahwa hipotesis alternatif (Ha) diterima dan hipotesis (Ho) ditolak yang menunjukkan adanya hubungan antara pengetahuan perawat dengan pelaksanaan keselamatan pasien (patient safety) di Rumah Sakit Pusri Palembang.

Hasil wawancara yang dilakukan peneliti terhadap responden di ruangan rawat inap, mereka mengatakan bahwa tidak semua perawat pelaksana di ruangan rawat inap memiliki pengetahuan yang baik tentang penerapan keselamatan pasien dan tidak semua perawat pelaksana mendapatkan pelatihan khusus tentang keselamatan pasien sehingga perawat pelaksana sering salah mengidentifikasipasien, mengidentifikasi dan pengelolaan risiko pasien yang kurang tepat, kurang memahami cara membuat asuhan pasien lebih aman, kurang memahami sasaran keselamatan pasien dan standar keselamatan pasien, pelaporan dan analisis insiden yang kurang sesuai, serta kurang memberikan solusi untuk meminimalkan timbulnya risiko dan mencegah terjadinya cedera yang disebabkan oleh kesalahan akibat melaksanakan suatu tindakan atau tidak mengambil tindakan yang seharusnya diambil.

Perawat pelaksana di ruangan rawat inap Rumah Sakit Umum Permata Madina Panyabungan memiliki pengetahuan yang baik tentang keselamatan pasien dan tidak semuanya mendapatkan pelatihan khusus tentang penerapan keselamatan pasien sehingga perawat pelaksana salah mengidentifikasi pasien, mengidentifikasi dan pengelolaan risiko pasien yang kurang tepat, kurang memahami cara membuat asuhan pasien lebih aman, kurang memahami sasaran keselamatan pasien dan standar keselamatan pasien, pelaporan dan analisis insiden yang kurang sesuai, serta kurang memberikan solusi untuk meminimalkan timbulnya risiko dan mencegah terjadinya cedera yang disebabkan oleh kesalahan akibat melaksanakan suatu tindakan atau tidak mengambil tindakan yang seharusnya diambil.

Adapun faktor-faktor yang dapat mempengaruhi tingkat pengetahuan seseorang 
menurut Notoatmodjo, yaitu: pendidikan, media massa/ informasi, usia, pengalaman, lingkungan, dan sosial budaya ekonomi. Pendidikan responden dalam penelitian ini lebih banyak yang berpendidikan Diploma tiga keperawatan, yang juga merupakan salah satu faktor yang menyebabkan kurangnya pengetahuan responden tentang penerapan keselamatan pasien.

\section{Hubungan Sikap dengan Penerapan Keselamatan Pasien di Ruangan Rawat Inap Rumah Sakit Umum Permata Madina Panyabungan}

Hasil uji validitas dan reliabilitas kuesioner sikap di ruangan rawat inap Rumah Sakit Umum Daerah Panyabungan menunjukkan bahwa tidak ada data yang mising (tidak dikenal) sehingga data penelitian ini merupakan data yang akurat dan selanjutnya dapat digunakan untuk penelitian. Nilai corrected item total correlaction dari 0,437-0,706 > 0,361 menunjukkan bahwa seluruh kuesioner sikap valid. Penyebaran kuesioner khusus dalam uji validitas dan reliabilitas diberikan kepada 30 responden yang memiliki karakteristik yang sama dengan sampel penelitian.

Hasil yang diperoleh menunjukkan bahwa seluruh pernyataan valid, karena seluruh pernyataan bernilai lebih besar atau sama dengan nilai $r$ tabel 0,361 . Hasil uji reliabilitas kuesioner sikap di ruangan rawat inap Rumah Sakit Umum Daerah Panyabungan diperoleh nilai $r$ alpha $>$ tabel $(0,666>0,361)$, hasil ini menunjukan bahwa seluruh kuesioner sikap reliabel.

Hasil penelitian yang dilakukan peneliti terhadap 35 responden di ruangan rawat inap Rumah Sakit Umum Permata Madina Panyabungan diperoleh bahwa lebih banyak jumlah responden yang bersikap dengan kategori baik dalam penerapan keselamatan pasien di ruangan rawat inap Rumah Sakit Umum Permata Madina Panyabungan sebanyak 30 responden $(94,3 \%)$, dan lebih sedikit responden yang bersikap dengan kategori kurang baik dalam penerapan keselamatan pasien sebanyak 5 responden $(14,3 \%)$.

Hasil uji Chi-square atau fisher's exact test dapat diketahui dengan derajat kemaknaan $(a)=0,05$ maka diperoleh nilai probabilitasnya $(\rho)=0,081>0,05$ menunjukkan bahwa tidak ada hubungan yang signifikan antara sikap perawat dengan penerapan keselamatan pasien di ruangan rawat inap Rumah SakitUmum Permata Madina Panyabungan.

Hasil penelitian ini sejalan dengan hasil penelitian yang dilakukan oleh Muhammad Fiki Fauzan dengan nilai $p$ value $=0,765>0,05$ dengan derajat kemaknaan ( $\alpha$ ) 0,05, yang menyatakan bahwa tidak ada hubungan yang signifikan antara sikap perawat dalam penerapan sasaran keselamatan pasien di ruang rawat inap Rumah Sakit Aulia Jakarta Selatan.

Hasil pengamatan yang dilakukan peneliti terhadap sikap perawat pelaksana dalam menerapkan keselamatan pasien di ruangan rawat inap Rumah Sakit Umum Permata Madina Panyabungan, mayoritas perawat pelaksana bersikap baik dalam menerapkan keselamatan pasien, walaupun perawat pelaksana memiliki pengalaman 
yang kurang banyak serta pengetahuan dan keterampilan yang kurang baik terhadap penerapan keselamatan pasien namun mereka selalu berusaha menerapkan sistem keselamatan pasien di rumah sakit agar pasien menjadi lebih aman, setiap terjadinya insiden keselamatan pasienharus dilaporkan, bukan untuk ditutupi atau disembunyikan, dan selalu memperhatikan keamanan obat yang harus diwaspadai.

Hal ini dipengaruhi oleh kepatuhan dan tanggungjawab setiap perawat pelaksana terhadap keselamatan pasien. Sikap dikatakan sebagai fungsi dari manusia seperti persepsi, motivasi dan berpikir yang seperti itu menunjukan hubungan-hubungan, bahwa sampai batas-batas tertentu perilakunya dapat diramalkan. Sikap yang baik dapat terwujud jika didasarkan pada tanggungjawab atas segala sesuatu yang telah dipilihnya dengan segala resiko yang merupakan sikap yang paling tinggi. Suatu sikap belum tentu otomatis terwujud dalam suatu tindakan (overt behaviour). Untuk mewujudkan sikap menjadi perbuatan nyata diperlukan faktor pendukung atau suatu kondisi yang memungkinkan seperti fasilitas.

\section{Hubungan Beban Kerja dengan Penerapan Keselamatan Pasien di Ruangan Rawat Inap Rumah Sakit Umum Permata Madina Panyabungan}

Hasil uji validitas dan reliabilitas kuesioner beban kerja di ruangan rawat inap Rumah Sakit Umum Daerah Panyabungan menunjukkan bahwa tidak ada data yang mising (tidak dikenal) sehingga data penelitian ini merupakan data yang akurat dan selanjutnya dapat digunakan untuk penelitian. Nilai corrected item total correlaction dari 0,407-0,661 > 0,361 menunjukkan bahwa seluruh kuesionerbeban kerja valid. Penyebaran kuesioner khusus dalam uji validitas dan reliabilitas diberikan kepada 30 responden yang memiliki karakteristik yang samadengan sampel penelitian.

Hasil yang diperoleh menunjukkan bahwa seluruh pernyataan valid, karena seluruh pernyataan bernilai lebih besar atau sama dengan nilai $r$ tabel 0,361 . Hasil uji reliabilitas kuesioner beban kerja di ruangan rawat inap Rumah Sakit Umum Daerah Panyabungan diperoleh nilai $\mathrm{r}$ alpha $>$ tabel $(0,615>0,361)$, hasil ini menunjukan bahwa seluruh kuesioner beban kerja reliabel.

Hasil penelitian yang dilakukan peneliti terhadap 35 responden di ruangan rawat inap Rumah Sakit Umum Permata Madina Panyabungan diperoleh bahwa lebih banyak jumlah responden dengan beban kerja kategori ringan dalam penerapan keselamatan pasien di ruangan rawat inap Rumah Sakit Umum Permata Madina Panyabungan sebanyak 18 responden $(51,4 \%)$, dan lebih sedikitresponden dengan beban kerja kategori berat dalam penerapan keselamatan pasiensebanyak 17 responden $(48,6 \%)$.

Hasil uji Chi-square atau Continuity Correction dapat diketahui dengan derajat kemaknaan $(a)=0,05$ maka diperoleh nilai probabilitasnya $(\rho)=0,126>0,05$ menunjukkan bahwa tidak ada hubungan yang signifikan antara beban kerja perawat dengan penerapan keselamatan pasien di ruangan rawat inap Rumah SakitUmum Permata Madina Panyabungan.

Hasil penelitian ini sejalan dengan hasil penelitian yang dilakukan oleh Nining Sri 
Ningsih dengan nilai $p$ value $=0,094>0,05$, yang menyatakan bahwa tidak ada hubungan yang signifikan antara beban kerja terhadap implementasi Patient Safety pada Perawat di Ruang Rawat Inap RSUD Balaraja.

Hasil wawancara yang dilakukan peneliti terhadap responden, mereka mengatakan bahwa beban kerja mereka di ruangan rawat inap tidak terasa berat karena mereka mengerjakannya dengan santai tapi cepat, tepat dan benar serta mempersepsikan pekerjaan sebagai pekerjaan yang mudah untuk dikerjakan atau diselesaikan seperti penerapan keselamatan pasien sesuai dengan standar operasional prosedur yang berlaku dirumah sakit umum Permata Madina Panyabungan, pekerjaan yang beragam jenisnya demi keselamatan pasien, kontak langsung dengan pasien secara terus menerus selama jam kerja, menyampaikan informasi mengenai status kesehatan pasien kepada pasien dan keluarganya, sehingga pekerjaan yang seharusnya berat terasa jadi mudah. Responden yang memiliki beban kerja dengan kategori berat terhadap penerapan keselamatan pasien di ruangan rawat inap Rumah Sakit Umum Permata Madina Panyabungan karena responden tersebut tidak mampu mempersepsikan pekerjaannya menjadi suatu pekerjaan yang mudah untuk diselesaikan.

\section{Sakit Umum Permata Madina Panyabungan}

Hasil uji validitas dan reliabilitas kuesioner supervisi di ruangan rawat inap Rumah Sakit Umum Daerah Panyabungan menunjukkan bahwa tidak ada data yang mising (tidak dikenal) sehingga data penelitian ini merupakan data yangakurat dan selanjutnya dapat digunakan untuk penelitian. Nilai corrected item total correlaction dari 0,451-0,687 $>$ 0,361 menunjukkan bahwa seluruh kuesioner supervisi valid. Penyebaran kuesioner khusus dalam uji validitas dan reliabilitas diberikan kepada 30 responden yang memiliki karakteristik yang sama dengan sampel penelitian.

Hasil yang diperoleh menunjukkan bahwa seluruh pernyataan valid, karena seluruh pernyataan bernilai lebih besar atau sama dengan nilai $r$ tabel 0,361 . Hasil uji reliabilitas kuesioner supervisi di ruangan rawat inap Rumah Sakit Umum Daerah Panyabungan diperoleh nilai $\mathrm{r}$ alpha $>$ tabel $(0,611>0,361)$, hasil ini menunjukan bahwa seluruh kuesioner supervisi reliabel.

Hasil penelitian yang dilakukan peneliti terhadap 35 responden di ruangan rawat inap Rumah Sakit Umum Permata Madina Panyabungan diperoleh bahwa lebih banyak jumlah responden supervisi dengan kategori kurang baik dalam penerapan keselamatan pasien di ruangan rawat inap Rumah Sakit Umum Permata Madina Panyabungan sebanyak 15 responden $(42,9 \%)$, dan lebih sedikit responden supervisi dengan kategori baik dalam penerapan keselamatan pasien sebanyak 15 responden $(42,9 \%)$.

Hasil uji Chi-square atau Continuity Correction dapat diketahui dengan derajat kemaknaan $(a)=0,05$ maka diperoleh nilai probabilitasnya $(\rho)=0,038<0,05$ menunjukkan bahwa ada hubungan yang signifikan antara supervisi dengan penerapan keselamatan pasien di ruangan rawat inap Rumah Sakit Umum Permata Madina Panyabungan. 
Hasil penelitian ini sejalan dengan hasil penelitian yang dilakukan oleh Nimade Nopita Wati dengan nilai $p$ value $=0,000<0,05$, yang menyatakan bahwa ada hubungan yang signifikan antara supervisi keperawatan dengan pelaksanaan budaya safety di ruangan rawat inap RSUD Sanjiwani Gianyar.

Hasil wawancara yang dilakukan peneliti terhadap responden, mereka mengatakan bahwa kepala ruangan kurang mengawasi perawat pelaksana dalam memberikan asuhan keperawatan baik secara langsung maupun tidak langsung, kurang membimbing bawahan dalam pembentukan tim setiap shift kerja dan merencanakan kegiatan atau program untuk identifikasi risiko keselamatan dan meminimalkan insiden, kurang mengarahkan bawahan atau perawat pelaksana untuk melaksanakan program patient safety sesuai standar operasional rumah sakit yang berlaku, kurang bertanggung jawab untuk mengikuti serah terima pasien setiap harinya sehingga penerapan keselamatan pasien di ruangan rawat inap Rumah Sakit Umum Permata Madina Panyabungan kurang baik.

\section{Pengaruh Pengetahuan dengan Penerapan Keselamatan Pasien di Ruangan Rawat Inap Rumah Sakit Umum Permata Madina Panyabungan}

Berdasarkan hasil penelitian yang telah dilakukan peneliti menunjukkan bahwa ada pengaruh pengetahuan dengan penerapan keselamatan pasien di ruangan rawat inap Rumah Sakit Umum Permata Madina Panyabungan dengan nilai $\mathrm{OR}=59, p$ value $=$ 0,008 . Kurangnya pengetahuan perawat tentang penerapan keselamatan pasien di ruangan rawat inap Rumah Sakit Umum Permata Madina Panyabungan berdampak pada keselamatan pasien. Hal ini dikarenakan perawat pelaksana di ruangan rawat inap memiliki pengetahuan yang kurang baik tentang penerapan keselamatan pasien dan tidak semua perawat pelaksana mendapatkan pelatihan khusus tentang keselamatan pasien sehingga perawat pelaksana sering salah mengidentifikasi pasien, mengidentifikasi dan pengelolaan risiko pasien yang kurang tepat, kurang memahami cara membuat asuhan pasien lebih aman, kurang memahami sasaran keselamatan pasien dan standar keselamatan pasien, pelaporan dan analisis insiden yang kurang sesuai, serta kurang memberikan solusi untuk meminimalkan timbulnya risiko dan mencegah terjadinya cedera yang disebabkan oleh kesalahan akibat melaksanakan suatu tindakan atau tidak mengambil tindakan yang seharusnya diambil.

Penelitian ini sejalan dengan penelitian yang dilakukan oleh Ari SetyaJatidengan nilai $\mathrm{F}$ hitung sebesar 22,496 > dari $\mathrm{F}$ tabel pada taraf signifikansi 5\% dan dk pembilang 1 dan dk penyebut 38 sebesar 4,10 sehingga dapat disimpulkan Ho ditolak dan $\mathrm{Ha}$ diterima artinya terdapat pengaruh yang signifikan antara pengetahuan terhadap perilaku penerapan standar keselamatan pasien pada perawat pelaksana di Instalasi Perawatan Intensif RSUD dr. Moewardi.

Terkait dengan konsep manajemen Sumber Daya Manusia (SDM), pengetahuan dinyatakan sebagai suatu syarat penting terbentuknya perilaku karyawan. Hal ini sejalan dengan pendapat Mangkuprawira yang menyatakan bahwa pengetahuan merupakan unsur pokok bagi setiap karyawan untuk merubah perilakunya dalam mengerjakan sesuatu. Perawat pelaksana yang hanya menggunakan pengetahuan yang sekedarnya akan semakin tertinggal kinerjanya dibanding karyawan yang selalu menambah pengetahuannya yang baru. Hal ini semakin memperjelas bahwa pengetahuan tidak hanya dapat dipandang 
sebagai investasi yang bermanfaat pada waktu tertentu saja akan tetapi bagaimana pengetahuan memengaruhi kinerja perawat pada periode pekerjaannya merupakan suatu hal yang penting diperhatikan dalam mengelola SDM.

Analisis peneliti terkait hal ini adalah upaya meningkatkan pengetahuan tetap merupakan suatu hal yang penting khususnya dalam konteks keselamatan pasien. Hal ini didukung oleh pendapat Notoadmodjo yang menyatakan bahwa pengetahuan yang menunjang keterampilan perlu diberikan agar staf dapat melakukan tugasnya berdasarkan teori-teori yang dapat dipertanggungjawabkan. Sejalan dengan hal ini juga Henriksen, Joseph, dan Zayas-Caban menyatakan bahwa keterbatasan pengetahuan SDM memiliki peran penting dalam menyebabkan keterbatasan institusi pelayanan untuk mengelola pelayanan yang berorientasi pada keselamatan pasien. Hal ini berarti bahwa keterbatasan pengetahuan merupakan hal kunci sangat perlu dipertimbangkan demi keamanan asuhan yang diberikan oleh perawat pelaksana.

\section{Kesimpulan}

Berdasarkan hasil penelitian yang telah diuraikan sebelumnya tentang faktor-faktor yang berpengaruh terhadap penerapan keselamatan pasien di ruangan rawat inap Rumah Sakit Umum Permata Madina Panyabungan maka dapat ditarik kesimpulan bahwa:

1. Ada pengaruh yang signifikan antara pengetahuan perawat terhadap penerapan keselamatan pasien di ruangan rawat inap Rumah Sakit Umum Permata Madina Panyabungan.

2. Tidak ada pengaruh yang signifikan antara sikap perawat terhadap penerapan keselamatan pasien di ruangan rawat inap Rumah Sakit Umum Permata Madina Panyabungan.

3. Tidak ada pengaruh yang signifikan antara beban kerja perawat terhadap penerapan keselamatan pasien di ruangan rawat inap Rumah Sakit Umum Permata Madina Panyabungan.

4. Ada pengaruh yang signifikan antara supervisi terhadap penerapan keselamatan pasien di ruangan rawat inap Rumah Sakit Umum Permata Madina Panyabungan.

\section{Referensi}

Departemen Kesehatan RI. Panduan Nasional Keselamatan Pasien. Rumah Sakit (patient safety). Jakarta: 2006.

Gibson J., Ivancevich J., Donnelly J. Organisasi: Perilaku, Struktur, Proses,Jilid 1. Jakarta: Binarupa Aksara Publisher; 2003.

Mona, N., 2020. Konsep Isolasi Dalam Jaringan Sosial Untuk Meminimalisasi Efek Contagious (Kasus Penyebaran Virus Corona Di Indonesia). Jurnal Sosial Humaniora Terapan, 2(2). Vancouver Mona N. Konsep Isolasi Dalam Jaringan Sosial Untuk Meminimalisasi Efek Contagious (Kasus Penyebaran Virus Corona Di Indonesia). Jurnal Sosial Humaniora Terapan. 2020.

Nur Hasanah, dkk. Hubungan Beban Kerja Perawat dengan Penerapan 
Keselamatan Pasien (Patient Safety) di Ruang Rawat Inap di Rumah Sakit Umum Raden Mattaher Jambi. 2017

Peraturan Menteri Kesehatan RI Nomor 11. tentang keselamatan pasien. 2017

Priyanto, Agus. Hubungan Tingkat Pengetahuan Dengan Perilaku Pencegahan

Kekambuhan Luka Diabetik. Jurnal Ners dan Kebidanan. Vol. 5 No. 3.

Kediri : STIKES Ganesha Husada. 2018.

Suryani, B. Panduan Yuridis Penyelenggaraan Praktik Kedokteran. Jakarta:Dunia cerdas; 2013

Undang-Undang RI Nomor 44. tentang Rumah Sakit. Jakarta: 2009.

Velliana D. Analisis Budaya Keselamatan Pasien Dalam Pelayanan Kesehatan di Rumah Sakit Muhammadiyah Unit II gamping. Tesis. 2015

Wawan A, Dewi M. Teori \& Pengukuran Pengetahuan, Sikap, Dan perilaku Manusia. Yogyakarta. Nuha Medika. 2010.

Widayatun, T. (2009). Ilmu perilaku Vol.2. Jakarta: Sagung Seto.Wiley. 